\title{
PENGARUH TIPE TUTUPAN LAHAN TERHADAP IKLIM MIKRO DI KOTA BITUNG
}

\author{
Yorri Y. J. Sanger \\ Rino Rogi \\ Johan A. Rombang
}

\begin{abstract}
This study aimed to analyze the effect of land cover types to micro-climate of and analyze the effect microclimate to the trees and open land towards amenities environment for human. The City of Bitung has selected as a research site because it planned for mega projects. They are Special Economic Zones (KEK), International Relations Ports and Manado-Bitung Highways. The research used primary and secondary data. The parameters measured for each land cover includes the elements of microclimate namely: Air Temperature, Humidity and Solar Radiation. Data analysis using techniques $T$ test, $F$ test and Analysis of amenities based on the data of air temperature and humidity, it can be calculated by Temperature Humadity Index (THI). The measurement results microclimate taken at four different land cover that is at the city park, Central Business District (CBD), housing and industry. The results of this study prove the hypothesis that there are differences in the average value of the temperature and humidity in the trees, open land. Tree vegetation structures more effectively reduce the air temperature. The structure of the vegetation canopy of trees that have rounded and more densely branched patterns, height being between 6-10 $\mathrm{m}$ and serves to overshadow proved more effective in improving amenities in the surrounding area. Based on the value of THI, all land cover both parks, CBD, residential and industrial categorized uncomfortable because the average is at a value $>27$. Housing area has very little green space. One of the efforts to improve the quality of the microclimate in order to enhance the user experience is to provide a good environment garden by planting vegetation predominant tree combined with shrubs and grasses to balance and harmonize between buildings and the environment also have aesthetic value. In the industrial area, the high levels of air pollution resulting from the production process so that recommended a good landscape arrangement, by expanding area of town forest and planting vegetation of trees that can absorb large numbers of pollutants result in healthy and fresh air for the region.
\end{abstract}

Keywords: land cover, micro-climate, amenities environment, Temperature Humidity Index (HTI), Bitung City

\begin{abstract}
ABSTRAK
Penelitian ini bertujuan untuk menganalisis pengaruh tipe tutupan lahan terhadap iklim mikro dan menganalisis pengaruh iklim mikro pada pohon serta lahan terbuka terhadap kenyamanan. Kota Bitung dipilih sebagai lokasi penelitian karena Kota Bitung merencanakan mega proyek seperti Kawasan Ekonomi Khusus (KEK), Pelabuhan Hubungan Internasional dan Jalan Tol Manado- Bitung. Data yang digunakan adalah data primer dan data sekunder. Parameter yang diukur pada setiap tutupan lahan meliputi unsur-unsur iklim mikro yaitu: Suhu Udara, Kelembaban Udara dan Radiasi Matahari. Analisis data menggunakan teknik Uji T, Uji F dan Analisis kenyamanan berdasarkan data suhu udara dan kelembaban udara maka dapat dihitung dengan Temperature Humadity Index (THI). Hasil pengukuran iklim mikro yang dilakukan pada empat tutupan lahan yang berbeda yaitu pada taman kota, CBD, perumahan dan industri. Penelitian ini membuktikan hipotesis yang menyatakan bahwa ada perbedaan nilai rata-rata suhu dan kelembaban udara pada pohon, lahan terbuka. Struktur vegetasi pohon lebih efektif mereduksi suhu udara. Struktur vegetasi pohon yang memiliki tajuk bulat dan pola percabangannya lebih rapat, tinggi pohon sedang antara 6-10 m serta berfungsi menaungi terbukti lebih efektif meningkatkan kenyamanan di daerah sekitarnya. Berdasarkan nilai THI, semua tutupan lahan baik taman kota, CBD (Central Business District), perumahan dan industri dikategorikan tidak nyaman karena rata-rata berada pada nilai > 27. Kawasan perumahan memiliki Ruang Terbuka Hijau (RTH) yang sangat minim. Salah satu upaya memperbaiki kualitas iklim mikro pada guna meningkatkan kenyamanan pengguna adalah dengan menyediakan taman lingkungan yang baik dengan penanaman vegetasi pohon paling mendominasi yang dikombinasikan dengan semak dan rerumputan untuk menyeimbangkan dan menyelaraskan antara bangunan dan lingkungan serta memiliki nilai estetika. Pada kawasan industri, tingginya tingkat pencemaran udara yang dihasilkan dari proses produksi sehingga direkomendasikan suatu penataan lanskap yang baik, dengan memperluas area hutan kota yang sudah ada dan menanam vegetasi pohon penyerap pencemar dalam jumlah yang banyak untuk mendapatkan udara kawasan yang sehat.
\end{abstract}

Kata kunci: tutupan lahan, iklim mikro, kenyamanan, Indeks Kelembaban Suhu (THI), Kota Bitung 


\section{PENDAHULUAN}

Cuaca dan iklim adalah proses interaktif alami (kimia, biologis, dan fisis) di alam, khususnya di atmosfer. Hal ini terjadi karena adanya sumber energi, yaitu Matahari dan gerakan rotasi Bumi pada poros (kurang 24 jam) serta revolusi Bumi mengelilingi Matahari. Cuaca sebagai kondisi udara sesaat dan iklim sebagai kondisi udara rata-rata dalam kurun waktu tertentu merupakan hasil interaksi proses fisis (Ditjen Penataan Ruang, 2007) . Lebih lanjut cuaca diartikan sebagai keadaan fisika udara pada suatu tempat tertentu dan dalam waktu tertentu yang realtif pendek (Utomo, 2009).

Cuaca dan iklim merupakan dua kondisi yang hampir sama tetapi berbeda pengertian khususnya terhadap kurun waktu. Cuaca merupakan bentuk awal yang dihubungkan dengan penafsiran dan pengertian akan kondisi fisik udara sesaat pada suatu lokasi dan suatu waktu, sedangkan iklim merupakan kondisi lanjutan dan merupakan kumpulan dari kondisi cuaca yang kemudian disusun dan dihitung dalam bentuk ratarata kondisi cuaca dalam kurun waktu tertentu (Winarso, 2003). Menurut Rafi'i (1995) Ilmu cuaca atau meteorologi adalah ilmu pengetahuan yang mengkaji peristiwa-peristiwa cuaca dalam jangka waktu dan ruang terbatas, sedangkan ilmu iklim atau klimatologi adalah ilmu pengetahuan yang juga mengkaji tentang gejala-gejala cuaca tetapi sifat sifat dan gejala-gejala tersebut mempunyai sifat umum dalam jangka waktu dan daerah yang luas di atmosfer permukaan bumi.

Trewartha, Horn (1995) mengatakan bahwa iklim merupakan suatu konsep yang abstrak, dimana iklim merupakan komposit dari keadaan cuaca hari ke hari dan elemen-elemen atmosfer di dalam suatu kawasan tertentu dalam jangka waktu yang panjang. Iklim bukan hanya sekedar cuaca rata-rata, karena tidak ada konsep iklim yang cukup memadai tanpa ada apresiasi atas perubahan cuaca harian dan perubahan cuaca musiman serta suksesi episode cuaca yang ditimbulkan oleh gangguan atmosfer yang bersifat selalu berubah, meski dalam studi tentang iklim penekanan diberikan pada nilai rata-rata, namun penyimpangan, variasi dan keadaan atau nilai-nilai yang ekstrim juga mempunyai arti penting. Selain itu Utomo (2009) mengemukakan bahwa iklim adalah generalisasi dari berbagai keadaan cuaca di daerah yang luas dalam waktu yang panjang.
Iklim selalu berubah menurut ruang dan waktu. Berdasarkan skal waktu tertentu perubahan iklim akan membentuk pola atau siklus tertentu, baik harian, musiman, tahunan maupun siklus beberapa tahunan. Selain perubahan yang berpola siklus, aktivitas manusia menyebabkan pola iklim berubah secara berkelanjutan, baik dalam skala global maupun skala lokal. Perubahan iklim didefinisikan sebagai perubahan pada iklim yang dipengaruhi langsung atau tidak langsung oleh aktivitas manusia yang merubah komposisi atmosfer, yang akan memperbesar keragaman iklim teramati pada periode yang cukup panjang (Trenberth, Houghton and Filho, 1995). Hidayati (2001) mendefinisikan perubahan iklim sebagai perubahan pada iklim yang dipengaruhi langsung atau tidak langsung oleh aktivitas manusia yang merubah komposisi atmosfer yang akan memperbesar keragaman iklim teramati pada periode yang cukup panjang. Studi tentang ciri-ciri tipikal iklim pada lapisan atmosfer bawah $(<2$ meter di atas permukaan tanah) disebut sebagai iklim mikro (micro climate) seperti iklim kota dan iklim hutan. Iklim mikro oleh Geiger didefinisikan sebagai iklim dalam ruang atau iklim dekat permukaan tanah (Utomo, 2009).

Iklim merupakan komposit cuaca, maka kondisi yang berkaitan dengan iklim mikro berkaitan juga dengan cuaca mikro. Secara khusus cuaca mikro (micro meteorology) mengkaji tentang gejala atmosfer skala kecil, terutama yang berhubungan dengan lapisan udara yang langsung berhubungan dengan tanah (Utomo, 2009). Cuaca suatu tempat merupakan total kondisi atmosfer (suhu, tekanan, angin, kelembapan, dan presipitasi) pada waktu pendek, sebab cuaca berbicara tentang hari ini atau minggu lalu (Utomo, 2009). Iklim mikro seperti yang diungkapkan sebagai iklim dalam ruang kecil (Dwiyono, 2009). Salah satu iklim mikro seperti halnya iklim perkotaan. Pada saat ini telah diakui bahwa iklim perkotaan memiliki karakteristik yang berbeda dengan iklim kawasan di sekitarnya yang masih memiliki unsur-unsur alami cukup banyak. Perubahan unsur-unsur lingkungan dari yang alami menjadi unsur buatan menyebabkan terjadinya perubahan karakteristik iklim mikro. Berbagai aktivitas manusia di perkotaan, seperti kegiatan industri dan transportasi, mengubah komposisi atmosfer yang berdampak pada perubahan komponen siklus air, siklus karbon dan perubahan ekosistem. Selain itu, polusi udara di perkotaan menyebabkan perubahan visibilitas dan daya serap atmosfer terhadap radiasi matahari. Radiasi matahari itu sendiri merupakan salah satu faktor utama yang menentukan karakteristik iklim di suatu daerah. 
Iklim perkotaan merupakan hasil dari interaksi banyak faktor alami dan antropogenik. Polusi udara, material permukaan perkotaan, emisi panas anthropogenik, bersama-sama dengan faktor alam menyebabkan perbedaan iklim antara kota dan area non perkotaan. Iklim suatu kota dikendalikan oleh banyak faktor alam, baik pada skala makro (seperti. garis lintang) maupun pada skala meso (seperti topografi, badan air). Pada kota yang tumbuh dan berkembang, faktor-faktor baru dapat mengubah iklim lokal kota. Guna lahan, jumlah penduduk, aktivitas industri dan transportasi, serta ukuran dan struktur kota, adalah faktor-faktor yang terus berkembang dan mempengaruhi iklim perkotaan.

Iklim mikro (suhu, kelembaban udara dan radiasi matahari) ditentukan oleh banyak faktor, baik faktor dalam skala lokal maupun dalam skala global. Perubahan yang cukup signifikan di sebagian belahan bumi dapat mempengaruhi suhu dan kelembaban di belahan bumi lainnya. Menurut Murdiyarso (2003) Suhu permukaan bumi meningkathingga $4,5^{\circ} \mathrm{C}$ dalam kurun waktu 100 tahun akan datang. Suhu Udara di Indonesia akan meningkat antara $1,0^{\circ} \mathrm{C}-1,5^{\circ} \mathrm{C}$ (Haryono, 2011) karenameningkatnya emisi gas $\mathrm{CO} 2$ disebabkan oleh perubahan tata guna lahan dan perusakan hutan, padahal hutan berfungsi sebagai penyerap gas $\mathrm{CO} 2$.

Hutan di Indonesia sering kali disebut sebagai paru-paru dunia, karena itu Indonesia sering dituduh sebagai salah satu penyebab perubahan suhu global, sejalandengan beberapa laporan baik pemerintah maupun lembagalembaga pemerhati kehutanan (LSM) melaporkan bahwa laju deforestrasihutan Indonesia meningkat hingga mencapai rata-rata 2 juta hektar tiap tahunnya (Barus, 1997). Laporan ini juga menyebutkanbahwa dua faktor utama penyebabkan kerusakan hutan adalah tekanan pertambahan penduduk dan adanya proyekproyek pembangunan yang luas yang mengekploitasi hutan untuk tujuan komersil.

Dalam skala lokal di setiap areal pemukiman penduduk, selalu diinginkan kondisi udara (termasuk suhu dan kelembaban) yang dianggap nyaman bagi manusia. Menurut Laurie (1986) iklim ideal bagi manusia adalah udara yang bersih dengan suhu udara kurang lebih $27^{\circ} \mathrm{C}$ sampai dengan $28^{\circ} \mathrm{C}$, dan kelembaban udara antara $40 \%$ sampai dengan $75 \%$. Akan tetapi kondisi seperti ini sering kali dalam jangka waktu tertentu dapat terjadi perubahan yang cukup drastis, akibat dari perubahan peruntukan lahan yang cukup siknifikan, karena berubahnya fungsi peruntukan. Bukan hanya manusia, vegetasi maupun hewan juga sering kali merasakan dampak yang tidak menguntungkan akibat perubahan kondisi iklim mikro (khususnya suhu dan kelembaban udara).

Perubahan peruntukan lahan akan terjadi di Kota Bitung karena lahan perkebunan dan pertanian yang peruntukannya berubah menjadi kawasan industri, pemukiman penduduk dan Central Bussiness District (CBD),sebab lahan di Kota Bitung akan dibangun mega proyek yaitu Kawasan Ekonomi Khusus, Internasional Hub Port dan Jalan Tol Manado-Bitung. Peruntukan lahan berhubungan dengan kumpulan aktivitas manusia yang berada pada sebidang lahan tertentu (Lillesand dan Kiefer 1979). Salah satu penyebab yang paling penting dari perubahan iklim adalah perubahan peruntukan lahan. Para ahli percaya bahwa perubahan peruntukan lahan akan menyebabkan dampak perubahan iklim yang lebih kuat dibandingkan dengan polusi yang menyebabkan pemanasan global (Tursilowati 2007).

Selain perubahan peruntukan lahan bertambahnya jumlah penduduk juga berpengaruh terhadap perubahan iklim mikro. Jumlah penduduk di Kota Bitung pada tahun 2014 mencapai 240.375 jiwa (data catatan sipil), dengan adanya Kawasan Ekonomi Khusus, Internasional Hub Port dan Jalan Tol ManadoBitung diperkirakan jumlah penduduk Kota Bitung kedepannyaakan mengalami pertambahan luar biasa melalui arus urbanisasi.

Salah satu solusi untuk meminimalisir penurunan kualitas lingkungan adalah dengan meningkatkan ketersediaan dan efektifitas dari Ruang Terbuka Hijau (RTH) pada kawasan kota. Perencana kota sudah seharusnya merencanakan ruang terbuka hijau (RTH) yang ideal bagi warga kota agar dapat memberikan kenyamanan dalam beraktivitas. Hal ini sudah diinstruksikan dalam bentuk UU RI No. 26 Tahun 2007 bahwa perbandingan luas RTH dengan ruang terbangun adalah 30\%: $70 \%$. Taman kota merupakan bagian dari bentuk RTH yang membantu meningkatkan kualitas ekologis dan lingkungan di sekitar taman itu berada. Sebagai bagian dari elemen pembentuk kota, taman kota memiliki banyak fungsi dalam kaitannya dengan kebutuhan jasmani dan rohani warga kota.

Ruang Terbuka Hijau (RTH) sebagai penyeimbang ekosistem kota baik itu sistem hidrologi, klimatologi, keanekaragaman hayati, maupun sistem ekologi lainnya, bertujuan meningkatkan kualitas lingkungan hidup, estetika 
kota, kesehatan, dan kesejahteraan masyarakat (Joga dan Iswan, 2011).Sehingga perlu dilakukan pengukuran agar dapat dianalisis perbedaan iklim mikro yang dihasilkan dan faktor penyebabnya untuk dapat menciptakan RTH yang lebih baik pada peruntukan lahanperkotaan.

\section{Perumusan Masalah}

Berdasarkan latar belakang yang telah diuraikan di atas, maka perumusan masalah dalam penelitian ini dapat dirumuskan sebagai berikut:

1. Bagaimana pengaruh tipe tutupan lahan terhadap iklim mikro (suhu udara, kelembaban udara dan radiasi matahari) ?

2. Bagaimana pengaruh iklim mikro (suhu udara, kelembaban udara dan radiasi matahari) pada pohon dan lahan terbuka terhadap kenyamanan?

\section{Tujuan Penelitian} adalah

Tujuan dari dilaksanakannya penelitian ini

1. Menganalisis pengaruh tipe tutupan lahan terhadap iklim mikro ( suhu udara, kelembaban udara dan radiasi matahari )

2. Menganalisis pengaruh iklim mikro (suhu udara, kelembaban udara dan radiasi matahari) pada pohon dan lahan terbuka terhadap kenyamanan.

\section{Manfaat Penelitian}

Penelitian ini diharapkan dapat memberi masukan mengenai pentingnya memperbaiki kualitas iklim mikro dengan meningkatkan kualitas Ruang Terbuka Hijau di Kota Bitung, sehingga dapat meminimalisir penurunan kualitas lingkungan dan meningkatkan kenyamanan warga di Kota Bitung dari segi iklim mikro.

\section{METODOLOGI PENELITIAN}

\section{Lokasi dan Waktu Penelitian}

Penelitian ini dilakukan di Wilayah Kota Bitung yang terletak di antara $1^{\circ} 23^{\prime} 23^{\prime \prime}$ $1^{\circ} 35^{\prime} 39^{\prime \prime}$ LU dan $125^{\circ} 1^{\prime} 43^{\prime \prime}$ - 125 $15^{\circ} 13^{\prime \prime}$ BT, dan berdasarkan data pada BPS (anonym, 2014) luas Kota Bitung mencapai 33.279,10 Ha. Kota Bitung dipilih sebagai lokasi penelitian karena Kota Bitung merencanakan mega proyek seperti Kawasan Ekonomi Khusus (KEK), Pelabuhan Hub Internasional dan Jalan Tol ManadoBitung. Waktu pelaksanaan penelitian ini pada bulan Agustus hingga September 2016.

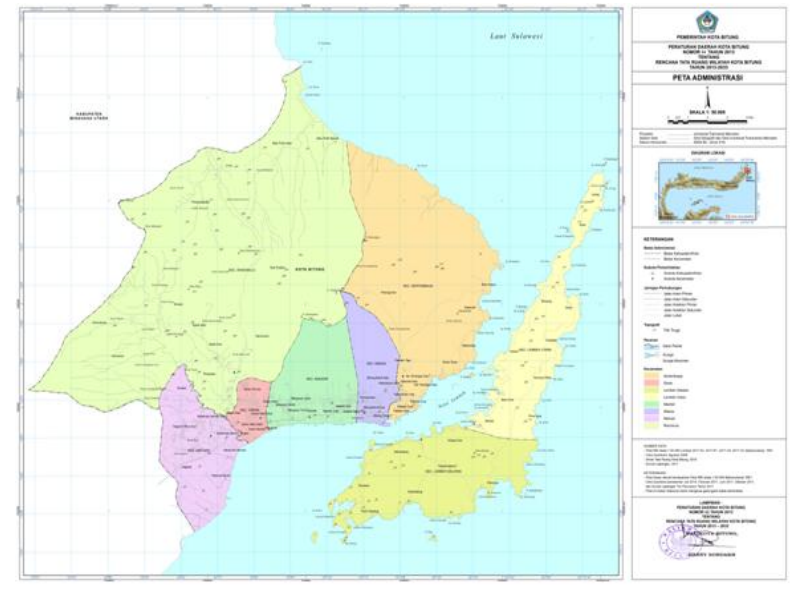

Gambar 1. Peta Administrasi Kota Bitung

\section{Alat dan Bahan}

Penelitian ini menggunakan beberapa alat dan bahan yang ditampilkan pada Tabel 1. Alat terpenting yang digunakan selama penelitian ini yaitu TermoHidro Meter dan Solar Power Meter, yang merupakan alat pengukur iklim mikro.

Tabel 1. Alat dan bahan Penelitian

\begin{tabular}{ll}
\hline \multicolumn{1}{c}{ Alat } & \multicolumn{1}{c}{ Kegunaan } \\
\hline TermoHidro & Mengukur Suhu dan \\
Meter & Kelembaban \\
\hline $\begin{array}{l}\text { Solar Power } \\
\text { Meter }\end{array}$ & $\begin{array}{l}\text { Mengukur Radiasi } \\
\text { Matahari }\end{array}$ \\
\hline Kamera Digital & $\begin{array}{l}\text { Pengambilan Gambar } \\
\text { Sampel }\end{array}$ \\
\hline GPS & Penitikan Sampel \\
\hline Data Citra Kota & Menghasilkan peta \\
Bitung & \\
\hline $\begin{array}{l}\text { Peta Kota } \\
\text { Bitung (RTRW) }\end{array}$ & Referensi \\
\hline Bahan Pustaka & Studi literatur, \\
& menghasilkan rekomendasi \\
\hline
\end{tabular}

\section{Data Penelitian}

Data yang digunakan dalam penelitian ini berupa data primer dan sekunder. Data primer adalah data yang langsung diambil oleh peneliti di lokasi penelitian sedangkan data sekunder adalah data yang diambil dari sumber-sumber literatur yang membantu peneliti dalam mengolah data.

\section{Parameter yang Diukur}

Parameter yang diukur pada setiap tutupan lahan meliputi unsur-unsur iklim mikro yaitu: Suhu Udara, Kelembaban Udara, Radiasi Matahari. 


\section{Metode Pengukuran}

Pengukuran iklim mikro berupa suhu udara, kelembaban udara dan radiasi matahari dilakukan pada setiap tutupan lahan (industri, pemukiman, Central Business District (CBD) dan Taman Kota) dengan 2 (dua) tempat pengambilan data di bawah pohon dan lahan terbuka. Untuk mengukur iklim mikro yang akurat, alat diletakkan $\pm 1,5$ meter di atas permukaan tanah dikarenakan menurut Frick H dan Suskiyanto FXB (2007) iklim mikro merupakan iklim di lapisan udara dekat permukaan bumi dengan tinggi \pm 2 meter. Data diambil selama 30 pada pukul 07.30, 13.30 dan 17.30 WITA dengan 5 (lima) kali ulangan, dilakukan hanya pada saat cuaca cerah.

\section{Pengolahan dan Analisis Data}

Setelah data iklim mikro berupa suhu udara, kelembaban udara dan radiasi matahari didapat, kemudian data ditabulasi dan dibuat grafik. Data yang sudah ada juga dianalisis secara statistik dengan teknik:

1. Uji $\mathrm{T}$ sehingga dapat diketahui perbedaan suhu udara, kelembaban udara dan radiasi matahari pada pohon dan lahan terbuka untuk setiap tutupan lahan (industri, pemukiman, CBD dan taman kota) pada pukul 07.30, 13.30 dan 17.30 WITA secara nyata atau tidak.

2. Uji $\mathrm{F}$ sehingga dapat diketahui perbedaan suhu udara, kelembaban udara dan radiasi matahari pada pohon dan lahan terbuka di berbagai tutupan lahan (industri, pemukiman, CBD dan taman kota).

3. Analisis kenyamanan berdasarkan data suhu udara dan kelembaban udara maka dapat dihitung Temperature Humadity Indeks (THI). Menurut Dahlan (2004), untuk mengkaji indeks kenyamanan di suatu lokasi digunakan rumus:

$$
\mathrm{THI}=0,8 \mathrm{~T}+\frac{\mathrm{RH} \times \mathrm{T}}{500}
$$

Keterangan :

THI : Temperature Humadity Index
T : Suhu Udara ( C)
RH : Kelembaban Nisbi Udara (\%)
Indeks kenyamanan di suatu lokasi
dikategorikan sebagai berikut (Laurie, 1986) :
THI = $21-27$ ( nyaman)
THI $>27$ (tidak nyaman)

\section{HASIL DAN PEMBAHASAN}

\section{Penutupan Lahan Kota BitungTahun 2016}

Hasil akurasi peta penutupan lahan Kota Bitung 2016 Lahan terbangun mendominasi perkembangan keseluruhan kota. Hal ini dapat dilihat dari kondisi eksisting kota Bitung yang sebagian besar tutupan lahannya terdiri dari kawasan perkantoran, pemukiman, industri dan perdagangan. Padatnya bangunan di sebagian besar wilayah Bitung dengan berbagai perkerasan lainnya berdampak pada berkurangnya lahan alami dan menurunnya kualitas kota.

Ketersediaan ruang terbuka hijau di Bitung sangat minim. Proporsi luas RTH yang ada saat ini akan berimplikasi pada keadaan iklim kota Bitung. Bitung menjadi lebih panas dan berdampak pada keseimbangan ekosistem kota dengan indikasi penurunan kualitas lingkungan seperti banjir pada musim hujan, fenomena heat island pada musim kemarau dan meningkatnya pencemaran kota.

\section{Iklim Mikro Kawasan Ruang Terbuka Hijau}

Luas ruang terbuka hijau di Bitung semakin lama semakin berkurang seiring dengan meningkatnya jumlah penduduk dan peningkatan kebutuhan lahan. Adanya batasan wilayah kota mendorong pembangunan cenderung memanfaatkan lahan-lahan alami yang masih ada, padahal lahan tersebut mempunyai fungsi-fungsi ekologis kota. Berkurangnya ruang terbuka hijau dan bertambahnya dominasi lahan terbangun di Bitung, berdampak pada keseimbangan ekosistem kota dengan indikasi kualitas lingkungan perkotaan. Taman kota, taman lingkungan dan taman rekreasi di Bitung pada umumnya berbentuk area hijau dengan luasan tertentu karena banyak digunakan masyarakat untuk berbagai kegiatan sedangkan ruang terbuka hijau berada di tepi jalan, sempadan sungai dan tepian pantai berbentuk koridor jalur hijau (green coridor). Bitung memiliki beberapa taman kota, salah satu taman kota yang cukup besar di Bitung adalah di Jl. S Dotulong..

Pengambilan data pada penelitian ini dilakukan di taman selama 5 hari mulai dari tanggal 10, 11, 12,17,18,19 Agustus 2016. Kawasan taman Kota didominasi vegetasi yang memilki jarak tanam yang rapat. 
Pengukuran suhu udara dan kelembaban udara dilakukan pada siang hari saat cuaca cerah yaitu pada pukul $07.30-08.00,12.30-$ $13.00,17.30-18.00$ WITA. Suhu dan kelembaban udara diukur di bawah naungan pohon - pohon dengan kepadatan tajuk yang cukup rapat. Data suhu udara dan kelembaban udara yang didapatkan dari hasil pengukuran selama lima hari. Data rata-rata ulangan pengukuran iklim mikro selama lima hari tersebut menunjukkan perbedaan setiap menit pengukuran baik pada pohon dan lahan terbuka. dilakukan pengukuran yaitu adanya tutupan awan yang mempengaruhi penyinaran matahari tetapi perubahan ini tidak cukup berarti karena saat berikutnya suhu kembali ke awal pengukuran. Rata-rata suhu udara pada pohon pukul 07.30 - 08.00, 12.30 - 13.00 dan $17.30-$ 18.00 secara berturut -turut adalah $30,5{ }^{\circ} \mathrm{C}, 31,6$ ${ }^{0} \mathrm{C}, 30.0{ }^{0} \mathrm{C}$ suhu udara dan pada lahan terbuka secara berturut- turut adalah $31,7^{\circ} \mathrm{C}, 36,2^{\circ} \mathrm{C}$, $30,1^{\circ} \mathrm{C}$. Data di atas menunjukkan bahwa suhu udara di bawah naungan pohon lebih rendah bila dibandingkan dengan lahan terbuka. Selisih suhu udara pohon dengan lahan terbuka secara berturut $1,2^{\circ} \mathrm{C}, 4,5^{\circ} \mathrm{C}, 0,1^{\circ} \mathrm{C}$ hal ini dikarenakan lahan terbuka mendapatkan sinar matahari secara langsung tanpa terlindungi oleh apapun sedangkan pohon masih memiliki naungan. Naungan secara langsung berpengaruh terhadap intensitas cahaya yang sampai dipermukaan tajuk tanaman. Selisih suhu udara terbesar pada pukul 12.30 - 13.00 wita, karena energi sinar matahari mengalami titik puncak sehingga suhu di lahan terbuka mengalami peningkatan yang besar. Keberadaan pohon dalam taman kota sangat erat kaitannya dengan pengaruh iklim mikro suatu kota.

Kelembaban udara pada setiap vegetasi di kawasan taman kota. Kelembaban udara paling tinggi dimiliki oleh vegetasi pohon. Di bawah naungan pohon, suhu udaranya lebih rendah dibandingkan dengan lahan terbuka. Namun, untuk kelembaban udara, pohon lebih tinggi. Nilai rata-rata kelembaban udara pada pohon 07.30 - 08.00, 12.30 - 13.00 dan 17.30 18.00 secara berturut -turut adalah $67,2 \%$, $65,3 \%, 68,9 \%$ dan lahan terbuka sebesar $62,3 \%$, $65,3 \%, 67,8 \%$ Selisih kelembaban udara pohon dan lahan terbuka 4,9\%,14,3\%,1,1\%. Pohon memiliki kelembaban udara yang lebih tinggi bila dibandingkan dengan lahan terbuka, hal ini disebabkan karena pohon yang satu dengan yang lainnya yang ada di RTH letaknya berdekatan dan cukup rindang. Faktor yang mempengaruhi keadaan tersebut yaitu kemampuan evapotranspirasi lebih baik karena tajuk pepohonan yang rapat sehingga kandungan uap air di bawah pohon lebih banyak. Dari hasil uji statistik melalui uji $\mathrm{T}$ dengan taraf nyata 0,05 terhadap pohon dan lahan terbuka terdapat perbedaan

\section{Iklim Mikro Kawasan CBD}

Kawasan pusat kota Bitung secara besarbesaran mengalami pergeseran fungsi lahan. Ruang terbuka hijau kota beralih fungsi menjadi kawasan bisnis, supermall, pekantoran dan sebagainya. Kawasan CBD (Central Business District) terdiri dari banyak bangunan dan perkerasan sehingga memiliki sedikit RTH. Keberadaan RTH pada kawasan ini, semakin lama semakin berkurang, proporsi antara bangunan dan RTH tidak seimbang sehingga memicu naiknya suhu udara. Salah satu kawasan CBD terbesar di kota Bitung adalah kawasan CBD Sam Ratulangi. Kawasan ini banyak terdapat gedung-gedung perbelanjaan, ruko, maupun gedung perkantoran. Akan tetapi, di CBD masih terdapat RTH yang cukup luas sehingga dilakukan pengukuran di lokasi ini karena area ini diasumsikan dapat mewakili seluruh kawasan CBD. Pengambilan data iklim mikro di kawasan CBD dilakukan selama lima hari.

Dari hasil uji statistik melalui uji $\mathrm{T}$ dengan taraf nyata 0,05 terhadap pohon dan lahan terbuka terdapat perbedaan pada pagi dan siang sedangkan sore hari tidak terdapat perbedaan. Suhu rata-rata pohon pada kawasan ini secara berturut - turut $31,8^{\circ} \mathrm{C}, 32,2^{\circ} \mathrm{C}$, $31,1^{\circ} \mathrm{C}$ sedangkan lahan terbuka memiliki suhu secara berturut - turut sebesar $32,7^{\circ} \mathrm{C}, 37,1^{\circ} \mathrm{C}$ dan $31,1^{\circ}$ C. Selisih suhu udara pukul $07.30-$ 08.00 wita antara pohon dan lahan terbuka pada kawasan CBD sebesar $0,9^{\circ} \mathrm{C}$, selisih suhu udara antara pohon dan lahan terbuka pukul 12.30 13.00 wita sebesar $3,9^{\circ} \mathrm{C}$ sedangkan selisih suhu udara antara pohon dengan rumput lvhan terbuka sebesar $0^{\circ} \mathrm{C}$ pada pukul $17.30-18.00$ wita. Suhu udara dibawah naungan pohon cenderung lebih kecil bila dibandingkan dengan suhu udara lahan terbuka. Hal ini disebabkan karena pohon memiliki tajuk yang dapat menyebarkan sinar matahari sehingga suhu area disekitarnya dapat direduksi dengan baik 
sedangkan semak memiliki area tajuk yang lebih kecil bila dibandingkan dengan pohon, sehingga kemampuan mereduksi suhu udaranya juga lebih rendah. Struktur vegetasi rumput memiliki suhu udara yang paling tinggi karena rumput menerima langsung sinar matahari tanpa terhalangi oleh apapun sehingga dipantulkan ke area sekitarnya.

Dari hasil uji statistik melalui uji $\mathrm{T}$ dengan taraf nyata 0,05 terhadap pohon dan lahan terbuka terdapat perbedaan nilai kelembaban udara. Dari hasil pengukuran dilapangan, pohon memiliki kelembaban suhu paling tinggi, hal ini dikarenakan suhu berbanding terbalik dengan kelembaban udara, semakin rendah suhu, semakin tinggi pula kelembaban udara. Rata-rata kelembaban udara pada pohon di kawasan CBD secara berturut turut sebesar $58,1 \%, 53,2 \%, 68,8 \%$ sedangkan untuk lahan terbuka secara berturut - turut memiliki kelembaban udara sebesar 50,9\%, $42,8 \%$ dan $67,9 \%$. Selisih kelembaban udara pohon dengan lahan terbuka pada kawasan CBD sebesar $7,2 \%$ pukul 07.30 - 08.00 wita. Selisih kelembaban udara pohon dengan lahan terbuka sebesar $20,3 \%$ pukul 12.30 - 13.00 wita sedangkan selisih antara kelembaban udara pohon dengan lahan terbuka adalah sebesar $0,9 \%$. Hal ini dikarenakan pohon dapat menghalangi masuknya sinar matahari, inilah yang menyebabkan area dibawah naungan pohon memiliki massa udara yang lembab.

\section{Iklim Mikro Kawasan Perumahan}

Kawasan pusat kota dan daerah pinggiran kota Bitung telah banyak mengalami konversi lahan. Lahan pertanian yang subur menjadi area komersil dan area pemukiman baru. Hal ini terjadi karena rencana tata ruang daerah yang telah di susun tidak begitu diperhatikan oleh developer. Peningkatan jumlah penduduk di kota Bitung yang semakin lama semakin meningkat menyebabkan warga Bitung berburu lahan untuk dijadikan kawasan bermukim. Dari hasil uji statistik melalui uji $\mathrm{T}$ dengan taraf nyata 0,05 terhadap pohon dan lahan terbuka terdapat perbedaan pada pagi dan siang sedangkan sore hari tidak terdapat perbedaan. Suhu rata-rata pohon pada kawasan ini secara berturut - turut $30,8^{\circ} \mathrm{C}, \quad 32,1^{\circ} \mathrm{C}, \quad 30,6^{\circ} \mathrm{C}$ sedangkan lahan terbuka memiliki suhu secara berturut - turut sebesar $32,3^{\circ} \mathrm{C}, 36,5^{\circ} \mathrm{C}$ dan $30,7^{\circ} \mathrm{C}$. Selisih suhu udara pukul $07.30-08.00$ wita antara pohon dan lahan terbuka pada kawasan perumahan sebesar $1,5^{\circ} \mathrm{C}$, selisih suhu udara antara pohon dan lahan terbuka pukul 12.30 - 13.00 wita sebesar $4,4^{\circ} \mathrm{C}$ sedangkan selisih suhu udara antara pohon dengan rumput lahan terbuka sebesar $0^{\circ} \mathrm{C}$ pada pukul $17.30-$ 18.00 wita. tertinggi adalah pohon. Suhu dibawah naungan pohon lebih rendah sehingga memiliki massa udara yang lembab.

Dari hasil uji statistik melalui uji $\mathrm{T}$ dengan taraf nyata 0,05 terhadap pohon dan lahan terbuka terdapat perbedaan nilai kelembaban udara. Dari hasil pengukuran dilapangan, pohon memiliki kelembaban suhu paling tinggi, hal ini dikarenakan suhu berbanding terbalik dengan kelembaban udara, semakin rendah suhu, semakin tinggi pula kelembaban udara. Rata-rata kelembaban udara pada pohon di kawasan perumahan secara berturut - turut sebesar $66,1 \%, 55,3 \%, 69,1 \%$ sedangkan untuk lahan terbuka secara berturut turut memiliki kelembaban udara sebesar $56,5 \%, 51,0 \%$ dan $68,1 \%$. Selisih kelembaban udara pohon dengan lahan terbuka pada kawasan perumahan sebesar 9,8\% pukul 07.30 - 08.00 wita. Selisih kelembaban udara pohon dengan lahan terbuka sebesar $14,3 \%$ pukul 12.30 - 13.00 wita sedangkan selisih antara kelembaban udara pohon dengan lahan terbuka adalah sebesar $0,9 \%$.

Hal ini membuktikan bahwa kemampuan setiap vegetasi dalam hal meningkatkan kelembaban udara berbeda-beda sesuai dengan karakteristik dari vegetasi itu sendiri. Luasan tajuk, lebar daun dan tinggi vegetasi berpengaruh secara nyata terhadap kenaikkan kelembaban udara.

\section{Iklim Mikro Kawasan Industri}

Kota Bitung mempunyai status sebagai pusat pemerintahan, perdagangan, industri, kebudayaan dan pariwisata. Sebagai pusat industri, Bitung memiliki tingkat polusi yang cukup tinggi. Aktivitas industri menimbulkan gas buang dan debu yang menjadi pencemar utama. Keberadaan RTH pada kawasan industri masih tergolong cukup minim, hanya beberapa kawasan industri saja yang memiliki hutan kota. Salah satu kawasan industri yang memiliki hutan kota yang cukup luas adalah kawasan PT. Sinar Pure Food Jl. Raya Madidir Unet, pada kawasan ini masih terdapat banyak vegetasi seperti pohon, semak maupun rumput. 
Pengukuran di kawasan industri PT. Sinar Pure Food Jl. Raya Madidir. Dari hasil uji statistik melalui uji $\mathrm{T}$ dengan taraf nyata 0,05 terhadap pohon dan lahan terbuka terdapat perbedaan pada pagi dan siang sedangkan sore hari tidak terdapat perbedaan. Suhu rata-rata pohon pada kawasan ini secara berturut - turut $31,3^{\circ} \mathrm{C}$, $33,8^{\circ} \mathrm{C}, \quad 31,1^{\circ} \mathrm{C}$ sedangkan lahan terbuka memiliki suhu secara berturut - turut sebesar $32,6^{\circ} \mathrm{C}, 37,4^{\circ} \mathrm{C}$ dan $31,2^{\circ} \mathrm{C}$. Selisih suhu udara pukul 07.30 - 08.00 wita antara pohon dan lahan terbuka pada kawasan industri sebesar $1,4^{\circ} \mathrm{C}$, selisih suhu udara antara pohon dan lahan terbuka pukul 12.30 - 13.00 wita sebesar $5,5^{\circ} \mathrm{C}$ sedangkan selisih suhu udara antara pohon dengan rumput lahan terbuka sebesar $0^{\circ} \mathrm{C}$ pada pukul $17.30-18.00$ wita. tertinggi adalah pohon. Suhu dibawah naungan pohon lebih rendah sehingga memiliki massa udara yang lembab.

Dari hasil uji statistik melalui uji $\mathrm{T}$ dengan taraf nyata 0,05 terhadap pohon dan lahan terbuka terdapat perbedaan nilai kelembaban udara. Dari hasil pengukuran dilapangan, pohon memiliki kelembaban suhu paling tinggi, hal ini dikarenakan suhu berbanding terbalik dengan kelembaban udara, semakin rendah suhu, semakin tinggi pula kelembaban udara. Rata-rata kelembaban udara pada pohon di kawasan perumahan secara berturut - turut sebesar 66,1\%, 55,3\%, 69,1\% sedangkan untuk lahan terbuka secara berturut turut memiliki kelembaban udara sebesar $56,5 \%, 51,0 \%$ dan $68,1 \%$. Selisih kelembaban udara pohon dengan lahan terbuka pada kawasan perumahan sebesar 9,8\% pukul 07.30 - 08.00 wita. Selisih kelembaban udara pohon dengan lahan terbuka sebesar $14,3 \%$ pukul 12.30 - 13.00 wita sedangkan selisih antara kelembaban udara pohon dengan lahan terbuka adalah sebesar $0,9 \%$.

\section{Iklim Mikro Struktur Vegetasi}

\section{Iklim Mikro Pohon}

Pohon sangat erat kaitannya dengan iklim mikro suatu daerah. Mekanisme hubungan pohon dan iklim mikro adalah ketika radiasi matahari diperkotaan mengakibatkan tanah dan benda lainya menjadi panas. Tumbuhan yang tinggi dan luasan yang cukup akan mengurangi efek pemanasan tersebut. Suhu udara pada daerah pepohonan lebih nyaman daripada daerah yang tidak ditumbuhi pohon. Hal ini disebabkan, daun-daun pada pohon dapat mengintersepsi, refleksi, mengabsorbsi dan mentransmisikan sinar matahari. Efektivitasnya tergantung kepada spesiesnya, misalnya rindang, berdaun, bercabang dan beranting banyak. Setiap spesies mempunyai bentuk, karakteristik, warna, tekstur dan ukuran berbeda-beda. Pohon secara ekologis dapat membantu meningkatkan kualitas udara dengan menurunkan iklim mikro, menyerap air dan polutan udara. Pohon juga dapat menyerap karbondioksida dan menghasilkan oksigen. Keberadaan pohon sangat diperlukan dalam ruang terbuka hijau pada setiap tutupan lahan di perkotaan. Namun, kebutuhan setiap land use berbeda-beda sehingga jenis pohon yang dibutuhkan akan berbeda-beda. Pada taman kota dan perumahan dibutuhkan pohon dengan fungsi pelindung dan pohon yang memiliki naungan yang cukup, karena pada kedua kawasan ini adalah area yang biasa digunakan untuk kegiatan bersosialisasi sehingga diperlukan kondisi sejuk dan nyaman. Untuk kawasan industri, dibutuhkan pohon yang dapat mengakumulasi berbagai jenis polutan dan dapat meredam kebisingan karena pada kawasan industri tingkat pencemaran udara cukup tinggi dihasilkan dari gas buang dan debu sebagai pencemar utama sedangkan untuk kawasan $\mathrm{CBD}$, dibutuhkan pohon yang dapat berfungsi sebagai peneduh, peredam kebisingan dan perlu diperhatikan bentuk dan karakteristiknya karena kawasan CBD sebagian besar berada dipinggir jalan. Pengukuran iklim mikro menggunakan alat dilakukan pada empat kawasan berbeda yaitu taman kota, CBD, perumahan dan industri. Pengukuran pada kawasan taman kota, CBD, perumahan dan industri, dilakukan dibawah pohon. Berikut grafik suhu dan kelembaban udara pohon pada empat kawasan berbeda di Kota Bitung.

Pada kawasan CBD dan pada kawasan industri memiliki suhu udara paling tinggi bila dibandingkan dengan dua kawasan lain. Suhu udara pohon pada kawasan perumahan dan industri hanya berbeda $0,6{ }^{\circ} \mathrm{C}$ saja pada pukul 12.30 - 13.00 wita, maka dapat diasumsikan suhu udara pohon pada kawasan industri dan CBD tidak jauh berbeda sedangkan pohon yang memiliki suhu paling rendah yang berada pada kawasan taman kota. Rata-rata suhu udara 
dibawah naungan pohon pada kawasan taman kota, perumahan, CBD dan industri berturutturut adalah $31,7{ }^{\circ} \mathrm{C} ; 32,1^{\circ} \mathrm{C} ; 33,2^{\circ} \mathrm{C}$ dan 33,8 ${ }^{\circ} \mathrm{C}$. Dari hasil uji statistik melalui uji $\mathrm{F}$ dengan taraf nyata 0,05 terhadap vegetasi pohon pada masing-masing tutupan lahan terdapat perbedaan nilai suhu udara pada struktur vegetasi yang sama yaitu vegetasi pohon pada semua tutupan lahan. faktor lingkungan dari lokasi pengukuran pada pohon di setiap tutupan lahan berbeda dapat mempengaruhi suhu udara. Kawasan industri banyak menghasilkan panas dari berbagai kegiatan produksi, asap pabrik dan kendaraan sehingga memiliki suhu udara yang panas sedangkan kawasan CBD memiliki suhu yang relatif tinggi disebabkan karena lokasi CBD dekat dengan kawasan industri sehingga suhu udara pada kawasan ini cenderung tidak jauh berbeda dengan industri. Selain itu, kawasan CBD minim keberadaan RTH.

Berbeda halnya dengan taman kota yang memilki suhu paling rendah dibandingkan dengan kawasan perumahan, industri maupun CBD. Hal ini dikarenakan pada taman kota didominasi oleh vegetasi yang memilki kerapatan yang tinggi sehingga dapat menurunkan suhu udara disekitarnya. Hal ini menunjukkan bahwa semakin tinggi nilai kerapatan pohon maka akan dapat mengurangi energi radiasi matahari sehingga dapat mereduksi suhu udara di sekitarnya dan iklim fisis atau keadaan udara pada suatu daerah akan berbeda karena dipengaruhi oleh tutupan lahan (vegetasi) dan pengaruh angin.

Pada data kelembaban udara di bawah naungan pohon pada empat tutupan lahan yang berbeda, pohon yang memiliki kelembaban udara paling tinggi adalah pada kawasan taman kota, dan kelembaban udara terendah pada kawasan indutri. Rata-rata kelembaban udara pohon sebesar $65,6 \%$ untuk kawasan taman kota 65,3\% untuk kawasan perumahan 63,2\% untuk kawasan CBD dan 62,6\% untuk kawasan industri. Dari hasil uji statistik melalui uji $\mathrm{F}$ dengan taraf nyata 0,05 terhadap vegetasi pohon pada masing-masing tutupan lahan di mana terdapat perbedaan nilai kelembaban udara pada struktur vegetasi yang sama yaitu vegetasi pohon pada semua tutupan lahan. Kelembaban udara pohon pada kawasan industri dan CBD tidak jauh berbeda hanya terdapat selisih $0,6 \%$ saja. Hal ini dapat disebabkan karena keadaan lingkungan yang tidak jauh berbeda di mana lokasi CBD tidak begitu jauh dari kawasan industri. Berbeda halnya dengan kawasan taman kota yang memiliki kelembaban udara pohon tertinggi, kawasan taman kota di dominasi oleh pepohonan dengan tingkat kerapatan yang cukup rapat. Pepohonan cenderung memiliki kelembaban udara yang tinggi karena aktivitas evapotranspirasi tanaman pada gerombolan pohon dapat meningkatkan kelembaban udara disekitarnya. Kelembaban udara akan semakin tinggi jika suhu makin rendah, namun bergantung pada kemampuan vegetasi dalam menaikkan kelembaban udara karena kemampuan setiap vegetasi berbeda-beda dalam meningkatkan kelembaban udara sehingga dapat disimpulkan bahwa kelembaban udara dibawah naungan tajuk akan relatif lebih tinggi karena adanya pengurangan penerimaan sinar matahari ke tajuk pepohonan.

\section{Iklim Mikro Lahan Terbuka}

Pengambilan data pukul 12.30 -13.00 wita menunjukkan bahwa suhu udara lahan terbuka pada empat kawasan berbeda yaitu taman kota, CBD, perumahan dan industri. Pada data terlihat bahwa suhu udara lahan terbuka tertinggi terdapat pada kawasan industri dan CBD sedangkan suhu udara lahan terbuka terendah terdapat pada kawasan perumahan dan taman kota. Hal ini terjadi karena adanya faktor lingkungan yang mempengaruhi kemampuan rumput dalam mereduksi suhu udara disekitarnya. Rata-rata suhu udara rumput pada kawasan taman kota adalah $36,2^{\circ} \mathrm{C}$, pada kawasan perumahan $36,5^{\circ} \mathrm{C}$, pada kawasan CBD $37,1^{\circ} \mathrm{C}$ dan pada kawasan industri $37,4{ }^{\circ} \mathrm{C}$. Dari hasil uji statistik melalui uji $\mathrm{F}$ dengan taraf nyata 0,05 terhadap lahan terbuka pada masing-masing tutupan lahan di mana perbedaan nilai suhu udara pada struktur vegetasi yang sama yaitu vegetasi rumput pada semua tutupan lahan. Suhu udara rumput pada kawasan industri dan kawasan CBD tidak jauh berbeda, selisih suhu udara antara kedua kawasan ini hanya $0,3{ }^{\circ} \mathrm{C}$ saja. Hal ini disebabkan oleh faktor lingkungan dimana lokasi pengukuran iklim mikro di kawasan perumahan dekat dengan kawasan industri. Selain itu, pada kedua kawasan ini dipengaruhi aktivitas industri yang menimbulkan panas sedangkan suhu udara rumput pada kawasan taman kota memiliki suhu udara terkecil karena pada kawasan taman kota cenderung didominasi oleh pepohonan dengan tingkat kerapatan yang tinggi. 
Pengambilan data pukul $12.30-13.00$ wita menunjukkan bahwa kelembaban udara rumput pada empat kawasan berbeda (taman kota, CBD, perumahan dan industri). Kelembaban udara rumput paling tinggi terdapat pada kawasan taman kota d Pengambilan data pukul $12.30-13.00$ wita perumahan sedangkan kawasan yang memilki kelembaban paling rendah adalah kawasan industri dan CBD karena kedua kawasan ini memilki nilai rata-rata kelembaban udara rendah. Rata-rata kelembaban udara rumput pada kawasan taman kota dan perumahan adalah $51,0 \%$, pada kawasan perumahan, $42,8 \%$ pada kawasan CBD dan industri memilki nilai rata-rata yang sama yaitu sebesar $36,7 \%$. Dari hasil uji statistik melalui uji dengan taraf nyata 0,05 terhadap vegetasi rumput pada masing-masing tutupan lahan di mana nilai probabilitas < dari 0,05 maka H0 di tolak sehingga terdapat perbedaan nilai kelembaban udara pada struktur vegetasi yang sama yaitu vegetasi rumput pada semua tutupan lahan.

Hasil penelitian ini selain mengetahui perbedaan ikim mikro antar struktur vegetasi RTH (pohon, semak dan rumput) pada empat kawasan berbeda, di analisis pula tingkat kenyamanan yang ditentukan dari hasil pengukuran iklim mikro pada keempat kawasan tersebut. Suhu udara dan kelembaban udara sangat berpengaruh terhadap aktivitas pengguna kawasan. Lingkungan yang nyaman dapat dirasakan pengguna untuk memenuhi kebutuhan fisik pengguna. Untuk menyatakan rasa nyaman tersebut secara kuantitatif maka diperlukan pengukuran THI (Temperature Humidity Indeks). Berikut adalah tabel pengukuran kenyaman struktur vegetasi pada empat kawasan yang berbeda pukul 12.30 13.00 wita.

\begin{tabular}{|c|c|c|c|c|c|c|}
\hline \multirow[t]{2}{*}{ No } & \multirow[t]{2}{*}{ Kawasan } & \multirow{2}{*}{$\begin{array}{l}\text { Struktur } \\
\text { Vegetasi }\end{array}$} & \multicolumn{3}{|c|}{ Faktor THI } & \multirow[b]{2}{*}{ Kategori } \\
\hline & & & $\begin{array}{c}\text { Suhu } \\
\text { Udara } \\
\left({ }^{0} \mathrm{C}\right)\end{array}$ & $\begin{array}{c}\text { RH } \\
(\%)\end{array}$ & THI & \\
\hline \multirow[t]{2}{*}{1} & Taman Kota & Pohon & 31,7 & 65,8 & 29,5 & Tidak Nyaman \\
\hline & & Lahan terbuka & 36,2 & 51,0 & 32,7 & Tidak Nyaman \\
\hline \multirow[t]{2}{*}{2} & Perumahan & Pohon & 32,1 & 65,3 & 29,9 & Tidak Nyaman \\
\hline & & Lahan terbuka & 36,5 & 51,0 & 33,0 & Tidak Nyaman \\
\hline \multirow[t]{2}{*}{3} & CBD & Pohon & 33,2 & 63,2 & 30,8 & Tidak Nyaman \\
\hline & & Lahan terbuka & 37,1 & 42,8 & 32,9 & Tidak Nyaman \\
\hline \multirow[t]{2}{*}{4} & Industri & Pohon & 33,8 & 62,6 & 31,2 & Tidak Nyaman \\
\hline & & Lahan terbuka & 37,4 & 36,7 & 32,6 & Tidak Nyaman \\
\hline
\end{tabular}

Tabel di atas menunjukkan nilai Temperature Humidity Indeks (THI) dari struktur vegetasi RTH (pohon, 1) di empat kawasan berbeda yaitu kawasan taman kota, CBD, perumahan dan industri. Pada tabel di atas terlihat bahwa semua struktur RTH pada empat kawasan tergolong kategori tidak nyaman. Hal ini disebabkan karena suhu udara pada semua kawasan berkisar antara $31,7{ }^{\circ} \mathrm{C}$ $37,4^{\circ} \mathrm{C}$, sedangkan untuk kelembaban udara disemua kawasan berkisar antara 36,7 - 65,8\%. Suatu tempat dikategorikan nyaman bila memilki nilai THI 21 - 27, jika > 27 maka dikategorikan tidak nyaman. Pada tabel, struktur vegetasi yang memilki nilai THI paling rendah pada kawasan taman kota, hal ini dikarenakan pada kawasan taman kota masih di dominasi oleh vegetasi sehingga menyebabkan pepohonan pada kawasan ini mampu mereduksi suhu dan merendahkan nilai THI.. Tingkat kenyamanan paling baik secara keseluruhan di setiap kawasan rata-rata berada pada struktur vegetasi pohon. Pohon dapat meningkatkan aktivitas evapotranspirasi sehingga dapat menurunkan suhu udara dan menaikkan kelembaban udara disekitarnya. Selain itu, pohon memiliki tajuk yang berfungsi menyebarkan sinar matahari yang masuk sehingga suhu udara di bawah naungan pohon lebih rendah bila dibandingkan dengan vegetasi yang lain.

Kawasan taman kota memilki nilai THI paling rendah yaitu berkisar 29,5-32,7. Hal ini karena pada taman kota masih didominasi oleh vegetasi sehingga memiliki nilai THI yang lebih rendah bila dibandingkan dengan kawasan lainnya. 


\section{KESIMPULAN DAN SARAN}

Kesimpulan

Berdasarkan tujuan dan hasil penelitian maka dapat di ambil beberapa kesimpulan antara lain :

1. Berdasarkan hasil pengukuran iklim mikro yang dilakukan pada empat tutupan lahan yang berbeda yaitu pada taman kota, CBD, perumahan dan industri, hasil penelitian ini membuktikan hipotesis yang menyatakan bahwa ada perbedaan nilai rata-rata suhu dan kelembaban udara pada pohon, lahan terbuka. Struktur vegetasi pohon lebih efektif mereduksi suhu udara. Struktur vegetasi pohon yang memiliki tajuk bulat dan pola percabangannya lebih rapat, tinggi pohon sedang antara 6-10 m serta berfungsi menaungi terbukti lebih efektif meningkatkan kenyamanan di daerah sekitarnya.

2. Berdasarkan nilai THI (Temperature Humidity Indeks), semua tutupan lahan baik taman kota, CBD, perumahan dan industri dikategorikan tidak nyaman karena rata-rata berada pada nilai $>27$

3. Kawasan perumahan memiliki RTH yang sangat minim. Salah satu upaya memperbaiki kualitas iklim mikro pada kawasan perumahan guna meningkatkan kenyamanan pengguna adalah dengan menyediakan taman lingkungan yang baik dengan penanaman vegetasi pohon paling mendominasi yang dikombinasikan dengan semak dan rerumputan untuk menyeimbangkan dan menyelaraskan antara bangunan dan lingkungan juga memiliki nilai estetika. Pada kawasan industri, tingginya tingkat pencemaran udara yang dihasilkan dari proses produksi sehingga direkomendasikan suatu penataan lanskap yang baik, dengan memperluas area hutan kota yang sudah ada dan menanam vegetasi pohon penyerap pencemar dalam jumlah yang banyak untuk mendapakan udara kawasan yang sehat.

\section{Saran}

Sebaiknya taman kota pada perkotaan dimanfaatkan sebaik-baiknya dengan cara merencanakan dan mendesain taman kota dengan struktur vegetasi yang sesuai sehingga keberadaan taman kota pada kawasan perkotaan dapat dengan efektif dalam ameliorasi iklim dan memberikan kenyamanan bagi warga kota. Peneliti juga berharap bahwa metode penelitian pada penelitian selanjutnya sebaiknya diambil pengukuran yang digunakan sebagai titik kontrol dan pertimbangan pemilihan lokasi pengambilan data ditambah variabelnya sehingga hasil penelitian lebih menginterpretasikan karakteristik dari iklim mikro pada penggunaan lahan yang berbeda..

\section{DAFTAR PUSTAKA}

Barus. 1997. Hutan Rakyat, Hutan Untuk Masa Depan. Yayasan Lestari Budaya. Jakarta.

Dwiyono. 2009. Pembangunan Pariwisata Berbasis Masyaraat. UNS Press. Surakarta

Ditjen Penataan Ruang. 2007. Ruang Terbuka Hijau Sebagai Unsur Utama Tata Ruang Kota. Dirjen Penataan Ruang

Haryono. 2011. Pedoman Umum Adaptasi Perubahan Iklim Sektor Pertanian. Badan Penelitian dan Pengembangan Pertanian. Bogor

Hidayati. 2001. Masalah Perubahan Iklim di Indonesia Beberapa. Program Pasca Sarjana / S-3. Institut Pertanian Bogor. Bogor

Joga dan Iswan. 2011. RTH 30\%! Resolusi (Kota) Hijau. PT Gramedia Pustaka Utama. Jakarta

Laurie. 1986. Pengantar Kepada Arsitektur Pertamanan (terjemahan). Intermata. Bandung. 
Lillesand dan Kiefer. 1979. Remote Sensing and Image Interpretation. John Wiley \& Sons. New York

Murdiyarso. 2003. Pemodelan Sistem Iklim. Badan Meteorologi Klimatologi dan Geofiksika. Jakarta

Rafi'i. 1995. Meteorologi dan Klimatologi. Angkasa. Bandung

Trenberth, Houghton and Filho. 1995. The Climate System : an Overview. In: Climate Change 1995. The Science of Climate Change. Contribution of Working group I to the Second Assesment Report of The Intergovermental Panel on Climate Change. Cambridge University Press
Trewartha, Horn. 1995. Pengantar Iklim. UGM Press. Yogyakarta

Tursilowati. 2007. Use of Remote Sensing and GIS to Compute Temperature Humidity Index as Human Comfort Indicator Relate With Tipe Tutupan Lahan-Land Cover Change (LULC) in Surabaya. Jurnal Ilmiah

Utomo. 2009. Komponen Perancangan Arsitektur Lansekap. Bumi Aksara. Jakarta

Winarso. 2003. Pengelolaan Bencana Cuaca dan Iklim untuk masa mendatang. KLH. Jakarta 